\title{
The Chilean Network of Microbial Culture Collections: Establishment and Operation
}

\author{
Red Chilena de Colecciones de Cultivos Microbianos: Establecimiento \\ y Operación
}
Cledir Santos $^{1 *}$, Paola Durán ${ }^{1}$, Gonzalo Tortela ${ }^{1}$, Leticia Barrientos ${ }^{1}$
Gabriela Briceño ${ }^{1}$, Rodrigo Rodriguez ${ }^{1}$, Patricio Godoy ${ }^{2}$, Eduardo Alvarez-Duarte ${ }^{3}$, Rodrigo Cruz Choappa ${ }^{4}$, Victor Silva ${ }^{5}$, Luiz Zaror ${ }^{5}$, Mariella Rivas ${ }^{6}$ \& Maria de La Luz Mora ${ }^{1}$
1. Chilean Culture Collection of Type Strains, BIOREN-UFRO -
Scientific and Technological Bioresource Nucleus,
Universidad de La Frontera, Temuco, Chile

2. Chilean Culture Collection of Filamentous Fungi and Yeasts,

Facultad de Medicina, Universidad Austral de Chile, Valdivia, Chile

3. Chilean Fungal Collection, Facultad de Medicina,

Universidad de Chile, Santiago, Chile

4. Colección Chilena de Hongos Patógenos Emergentes,

Universidad de Valparaíso, Valparaíso, Chile

5. Microbial Culture Collection of the Universidad Mayor, Universidad Mayor, Campus Huechuraba,

Santiago de Chile, Chile

6. Microalgae Collection of Atacama Desert, Universidad de Antofagasta,

Antofagasta, Chile

* Correspondence author: cledir.santos@ufrontera.cl

RECIBIDO:08 de Noviembre de 2016 APROBADO:10 de Noviembre de 2016

DOI: 10.22370/bolmicol.2016.32.2. 491

LOS AUTORES DECLARAN NO TENER CONFLICTO DE INTERESES

Palabras clave: Colecciones de cultivos; cepas microbianas; Chile.

Key words: Culture collections; microbial strains; Chile.

ABSTRACT

According to the data available at the World Data Center for Microorganism-WDCM from the
World Federation for Culture Collection-WFCC, Chile has four registered culture collections that preserve 2777 microbial strains. At the global point of view, the culture collections in Chile are in 
different level of operation regarding its own infrastructure and compliancy with quality standards for preservation of strains and for services provide. The absence of funding to support the preservation of the Chilean microbial assets is a key issue for the development of the Chilean bioeconomy. Considering this, the Chilean culture collections started working together to establish the Chilean Network of Microbial Culture Collections (RCCCM, acron$\mathrm{ym}$ in Spanish). In this note, the establishment and operation of the RCCCM is presented and discussed.

\section{RESUMEN}

De acuerdo con los datos disponibles en el World Data Center for Microorganism-WDCM de la Federación Mundial para la Colección de Cultivos - WFCC, Chile tiene cuatro colecciones de cultivos registradas que preservan 2777 cepas microbianas. Desde el punto de vista global, las colecciones de cultivos en Chile se encuentran en diferentes niveles de operación con respecto a su propia infraestructura y cumplimiento con estándares de calidad para la preservación de las cepas y para los servicios que proporcionan. La ausencia de financiamiento para apoyar la preservación de los activos microbianos chilenos es un tema clave para el desarrollo de la bioeconomía chilena. Considerando esto, las colecciones chilenas de cultivos comenzaron a trabajar conjuntamente para establecer la Red Chilena de Colecciones de Cultivos Microbianos (RCCCM). En esta nota se presenta y discute el establecimiento y funcionamiento de la RCCCM.

\section{Microbial assets and the bioeconomy-based de- velopment}

The bio-industries have played a significant role in economic development of the countries around the World. Estimations for the bio-industry market have increased over the years. Furthermo- re, according to the Organisation for Economic Cooperation and Development-OECD, within 2030 years ahead, bio-applications will be part of a daily life with better health, cleaner environment and more sustainable energy production. It will be translated in a better quality of life and well-being of people around the world (OECD, 2001).

According to OECD, bioeconomy is defined as part of the economy that incorporates the value of the core of biological processes and biorenewable resources to produce better health and sustainable development. In this context, microorganisms represent a treasure still intact to be used and to explore new functions and create new products with added-value.

The microbial resources of our planet are vital to humanity's economic and social development. Microorganisms such as bacteria, archaea, viruses, viroids, filamentous fungi, yeasts, microalgae and protozoans, comprise the greatest numbers of organisms on Earth. Nowadays, the importance of ex situ preservation for the use of microbial resources is undeniable. microBiological Resource Centres (mBRCs) are essential infrastructures to preserve microbial resources and serves as base for development of research in different scientific fields such as chemistry, biology, pharmacy, agriculture, biotechnology, etc.

The quality control of microbial resources preserved and provided in mBRCs around the world is critical. Only working based on international standard quality systems (Simões et al., 2016), mBRCs will be able to supply microbiological materials to their user's communities with guaranty of harmonised international quality in compliance with the national and international legal frameworks (e.g., Convention of Biological Diversity and, more recently, the Nagoya Protocol).

microBiological Resource Centres are per se an international issue. According to the data available at the World Data Center for Microorganism-WDCM from the Word Federation for Culture Collection-WFCC, Chile has four registered 
culture collections that preserve 2777 microbial strains (WDCM, 2016). Moreover, according to Overmann (2015) Andean Countries are recognised as little capacity building states, once eleven culture collection are available with the focus on microbiological strains from the Andean region.

Chile is already a full member country of OECD with an economic and societal development that ranks it in a good international position (together with European Union countries). In addition, expertise and infrastructure for scientific research and development is already available across the country.

In contrast, the national scenario of the microbial culture collections is characterised by an absence of funding from both public and private sectors. Moreover, no clear guidance for microbial ex situ preservation and usage is observed in the country. For these reasons, Chile is not in a good situation concerning its culture collections as infrastructures of national interest. In this context, Chile is comparable to those situations found in the entire African continent and the Andean region of South America, as stated by Overmann (2015). In order to change the scenario of microbial culture collections in Chile, engaged and focused efforts in this subject are required.

\section{Establishment and Operation of the Chilean Network of Microbial Culture Collections}

Facing the limitation of low availability of microbial resources and information, and in order to a better understanding about the Chilean native microbial diversity, special efforts are required from public and private sector in Chile. It will certainly underpin the future of the economic development of Chile, which will be translated in a wellbeing for its society.

The BIOREN-UFRO-Scientific and Technological Bioresource Nucleus of the Universidad de La Frontera, located at the Southern Chilean region of the La Araucanía, hosts the Chilean Culture Collection of Type Strains - CCCT/UFRO (http:// ccct.ufro.cl/). The CCCT/UFRO is a public service culture collection that preserves and supplies microbial strains, manly those related with the Chilean biomes, that includes the Andean, Atacama Desert, Chilean Antarctic Territory, Pascua Island, and South American and Austral Pacific Ocean. The CCCT/UFRO is member of the WFCC and is registered at the WDCM under the number 1111. In January 2016, the CCCT/UFRO was the first Chilean Microbial Culture Collection to join GCMGlobal Catalogue of Microorganisms (http://gcm. wfcc.info/).

In addition, the Instituto de Investigaciones Agropecuarias-INIA, located at the Chilean Region of Bío Bío, hosts the Chilean Collection of Microbial Genetic Resources-CChRGM (www. cchrgm.cl). The CChRGM is also a public service culture collection that preserves and distributes microbial strains, manly bacteria and fungi of agricultural relevance. The CChRGM is member of the WFCC registered at the WDCM under the number 1067 and has acquired in 2012 the status of International Depositary Authority-IDA under the Budapest Treaty. In July 2016, the CChRGM join also the GCM.

Located at the Metropolitan Region of Santiago de Chile, the Chilean Fungal Collection - $\mathrm{ChFC}$ is another public service culture collection that preserves and supplies microbial strains. The ChFC is hosted by the Universidad de Chile and its focus is on the clinical filamentous fungi and yeasts. The ChFC is member of the WFCC registered at the WDCM under the number 1077.

The Culture Collection of the Biotechnology Center-CUC (www.centrobiotecnologia.cl), hosted by the Center of Biotechnology of the Universidad de Concepción, is also a public service culture collection that preserves and supplies microbial strains. It is located at the Chilean Region of Bío Bío and is registered at the WDCM under the number 830 .

Moreover, there are other public services Culture Collections in Chile operating at national 
and international level that are not yet members of the WFCC. Overall, some of these Chilean infrastructures are high specialised culture collections, focused in specific taxonomic microbial groups providing services in its field of knowledge. In contrast, at the global point of view, the culture collections in Chile are in different level of operation regarding its own infrastructure and compliancy with quality standards for preservation of strains and for services.

Take into consideration the absence of funding to support the preservation of the Chilean microbial assets, the Chilean culture collections started working together to establish the Chilean Network of Microbial Culture Collections (RCC$\mathrm{CM}$, acronym in Spanish).
At the current stage, the RCCCM has been constructed based on a MoU-Memorandum of Understanding, which involves the follow Microbial Culture Collections: CCCT/UFRO (WDCM 1111); ChFC (WDCM 1077); CChRGM(WDCM 1067); the Microalgae Collection of Atacama Desert-MCAD, hosted by the Universidad de Antofagasta (Antofagasta, Chile); the Chilean Culture Collection of Filamentous Fungi and YeastsCCHFL, hosted by the Austral University of Chile (Valdivia, Chile); the Microbial Culture Collection of the Universidad Mayor-MCCUM, hosted by the Universidad Mayor (Santiago de Chile, Chile); the Colección de Recursos Microbianos de Interés Industrial - CRMIICB-UdeC, hosted by the Universidad de Concepción (Concepción, Chile),

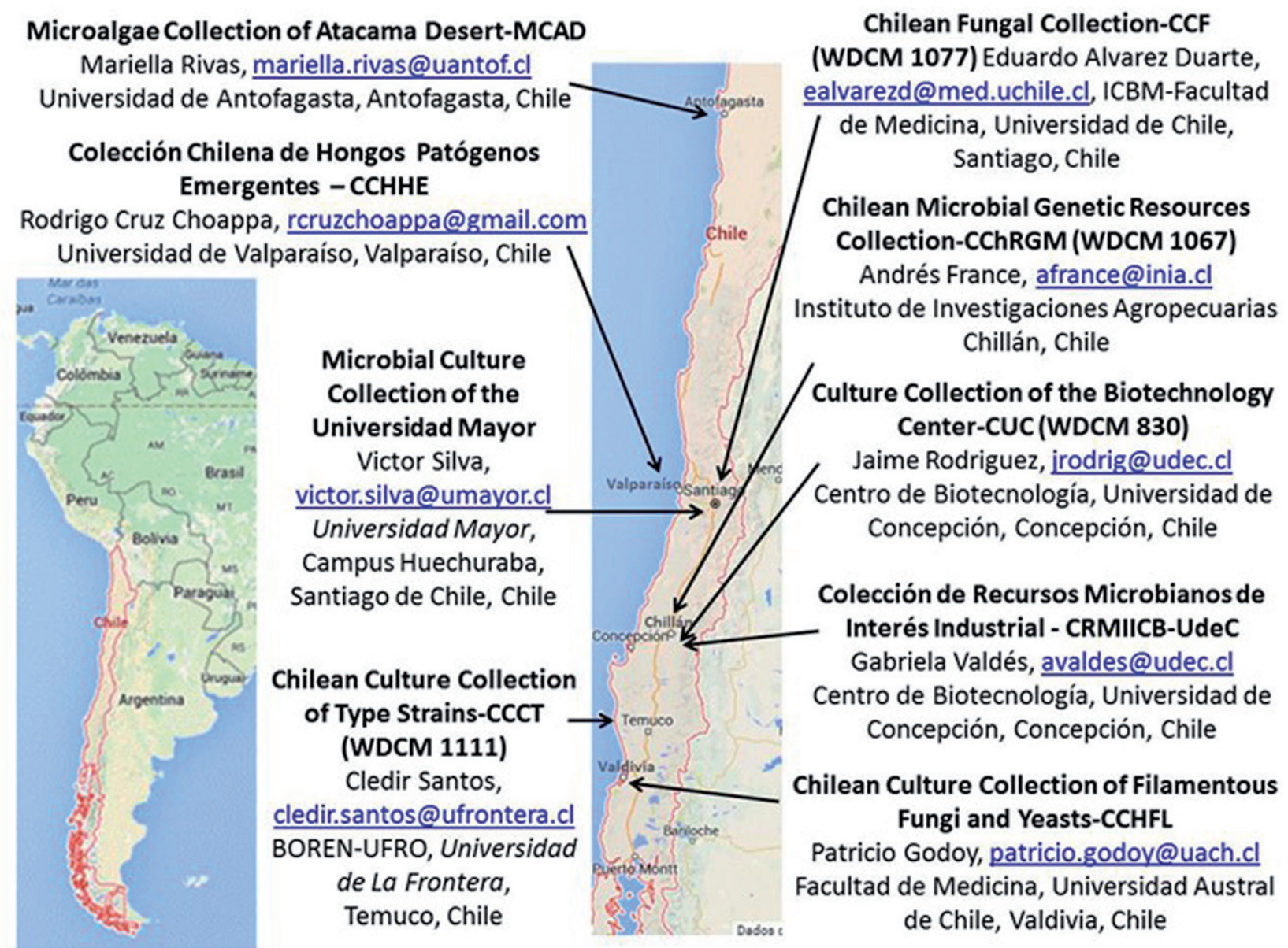

Figure 1: Geographical distribution and the contact person of each Culture Collection in Chile. The members of the WFCC have their registration WDCM number mentioned. 
and the Colección Chilena de Hongos Patógenos Emergentes - CCHHE, hosted by the Universidad de Valparaíso (Valparaíso, Chile)(Figure 1).

With the MoU drafted (Figure 2 a) the RCCCM was established in October 2015 and the kick-off meeting took place at the BIOREN-
UFRO (Universidad de La Frontera, Temuco) at November $16^{\text {th }} 2015$ (Figure 2 b). Currently, the RCCCM's MoU is under juridical evaluation to be signed by each member of the RCCCM. In addition, the Chilean Arms participates in the RCC$\mathrm{CM}$ as Invited Observer without right to vote and

\section{RED CHILENA DE COLECCIONES DE CULTIVOS MICROBIANOS \\ -RCCCM- MEMORANDO DE ENTENDIMIENTO}

\section{La construcción y operación de la Red Chilena de Colecciones de Cultivos Microbianos (RCCCM)}

a)

Desde el siglo pasado la industria petroquímica ha sido la base del desarrollo económico de los paises y de las economías. Los productos petroquímicos son todavía ampliamente utilizados en la agricultura, en la producción de plásticos, fibras sintéticas, explosivos, y en las industrias de automóviles y de aviación. Sin embargo, los problemas ambientales y la baja en la disponibilidad del crudo son algunas de las preocupaciones para el futuro de la industria basada en la petroquimica.

En paralelo a la industria petroquímica, las bio-industrias han jugado un papel importante en el desarrollo económico. Las demandas para el mercado de las bioindustrias han aumentado con los años. Además, según la Organización para la Cooperación y el Desarrollo Económico (OCDE), en los 20-30 años venideros, las bioaplicaciones serán parte de una vida cotidiana más saludable, un medio ambiente más limpio y la producción sustentable de energia. Esto se traducirá en una mejor calidad de vida y bienestar social para las personas en todo el mundo.

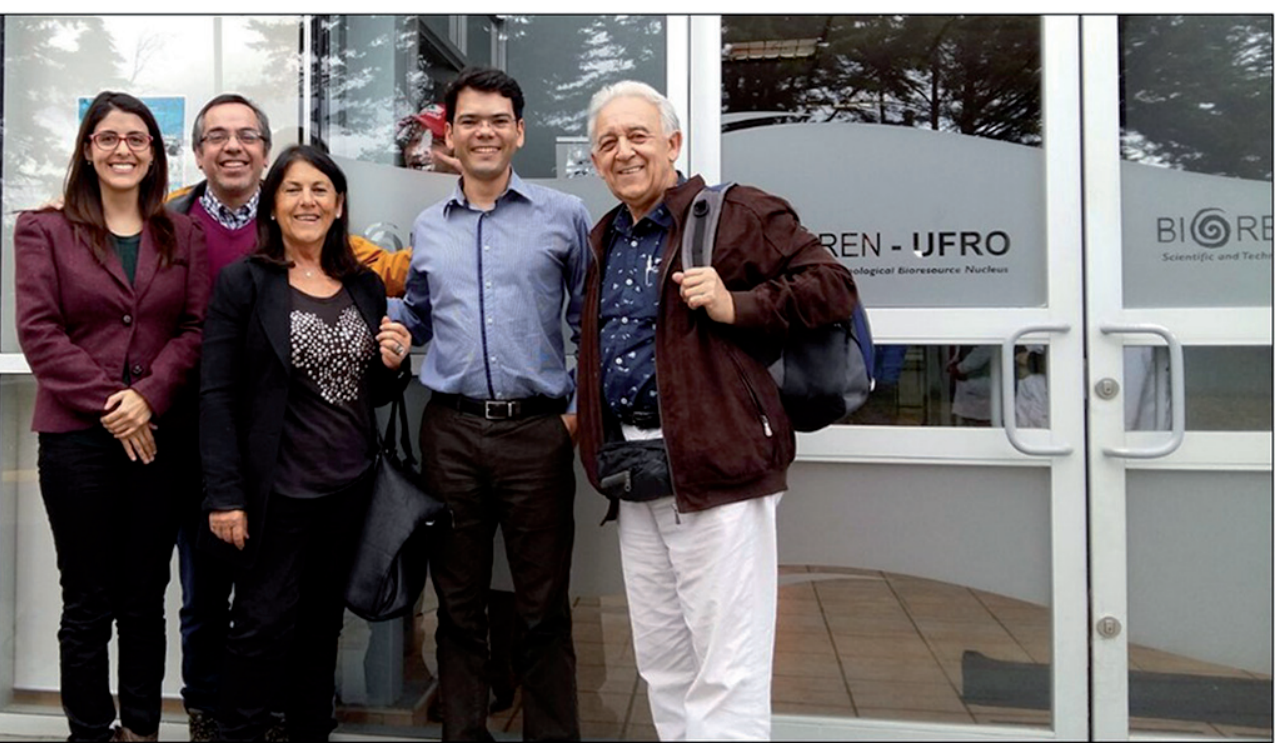

Figure 2: a) Part of the RCCCM's MoU under evaluation. b) Photography of the first meeting held at BIOREN-UFRO (Temuco, Chile) for the establishment of the RCCCM. From the left to the right: Ms. Alejandra Teneo (representative of the Department of Control of War Material, Chile), Dr. Patricio Godoy (Head of CCHFL), Dr. Maria de La Luz Mora (Director of BIOREN-UFRO), Dr. Cledir Santos (Head of CCCT/UFRO), Dr. Luis Zaror (Deputy of MCCUM). 
is represented by the Army Major Marisol Oryan (moryan@dgmn.cl, Biological Weapons Convention Department of Control of War Material, Santiago of Chile).

The RCCCM's MoU establishes the general bases for cooperation between the parties (i.e. the Microbial Culture Collections underwritten in the "List of Members Signatories"). Moreover, according to the MoU, the Parties agree to work in agreement to implement Quality Standards according to the Best Practice Guidelines established by the OECD for Microbial Resources Centres-mRBC (OECD, 2007) (Figure 3).

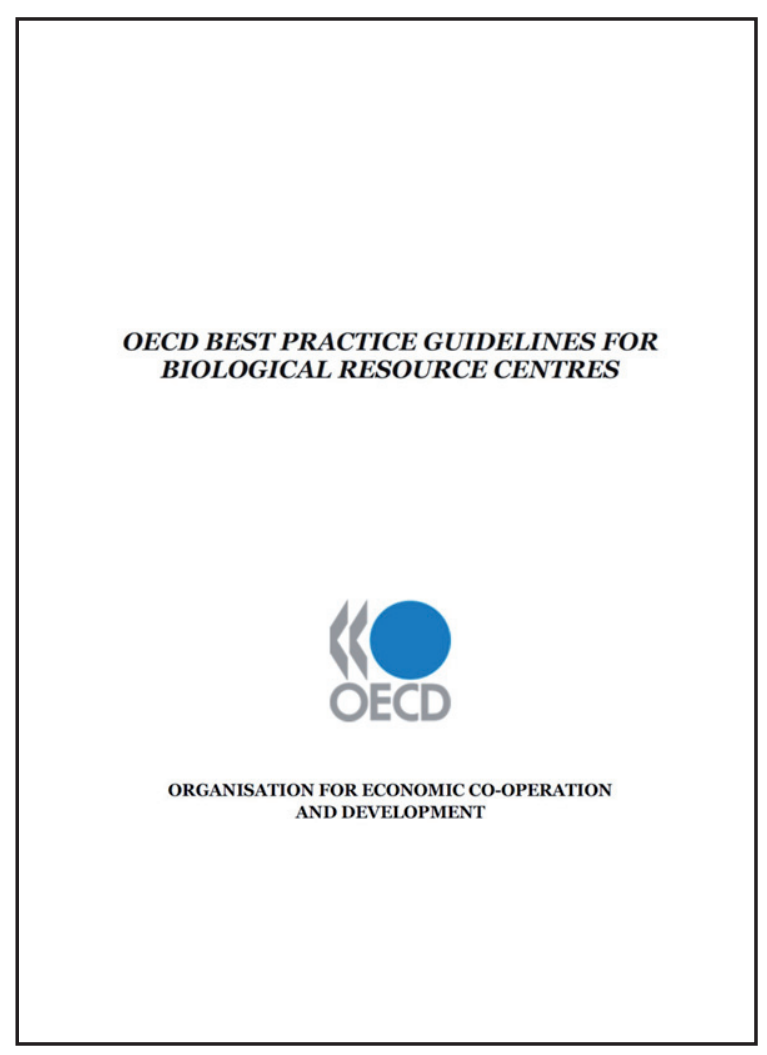

Figure 3. Cover of the OECD best practice guidelines for Biological Resources Centres.
It means that the main aim of the RCCCM is the harmonisation of the quality of biological material preserved and its related data and provided services to support the development of the Chilean bioeconomy based on the knowledge through clean and eco-friendly biological processes. It will surely help Chile to become a more competitive economy based on the knowledge.

Researchers belonging to these culture collections are working together to move forward in the concept of mBRC in Chile, where each preserved strain has to be submitted to a battery of morphological, physiological and molecular tests for its identification and characterisation. In order to determine the strains identity, as part of the authentication process, these traits are compared with the description of each taxa.

The establishment of a specialised national distributive infrastructure for microbial preservation (national $\mathrm{mBRC}$, Figure 5) focused on the economical and societal developments of Chile is pivotal. The preservation and availability of the microbial assets, and their associate information, in this distributive mBRC, will contribute to Chile gain a competitive position at international level. The conection of the RCCCM with other national, regional and global microbial culture collection networks and Initiatives will help Chile to leave the current situation of spectator and led the country to a key player at international level (Figure 5).

\section{ACKNOWLEDGEMENT}

C. Santos thanks to the Universidad de La Frontera for the partial funding to the development of this work through the Project PIA16-0009. Authors thank to the Universidad de La Frontera to the financial support in the international dissemination of the RCCCM. 

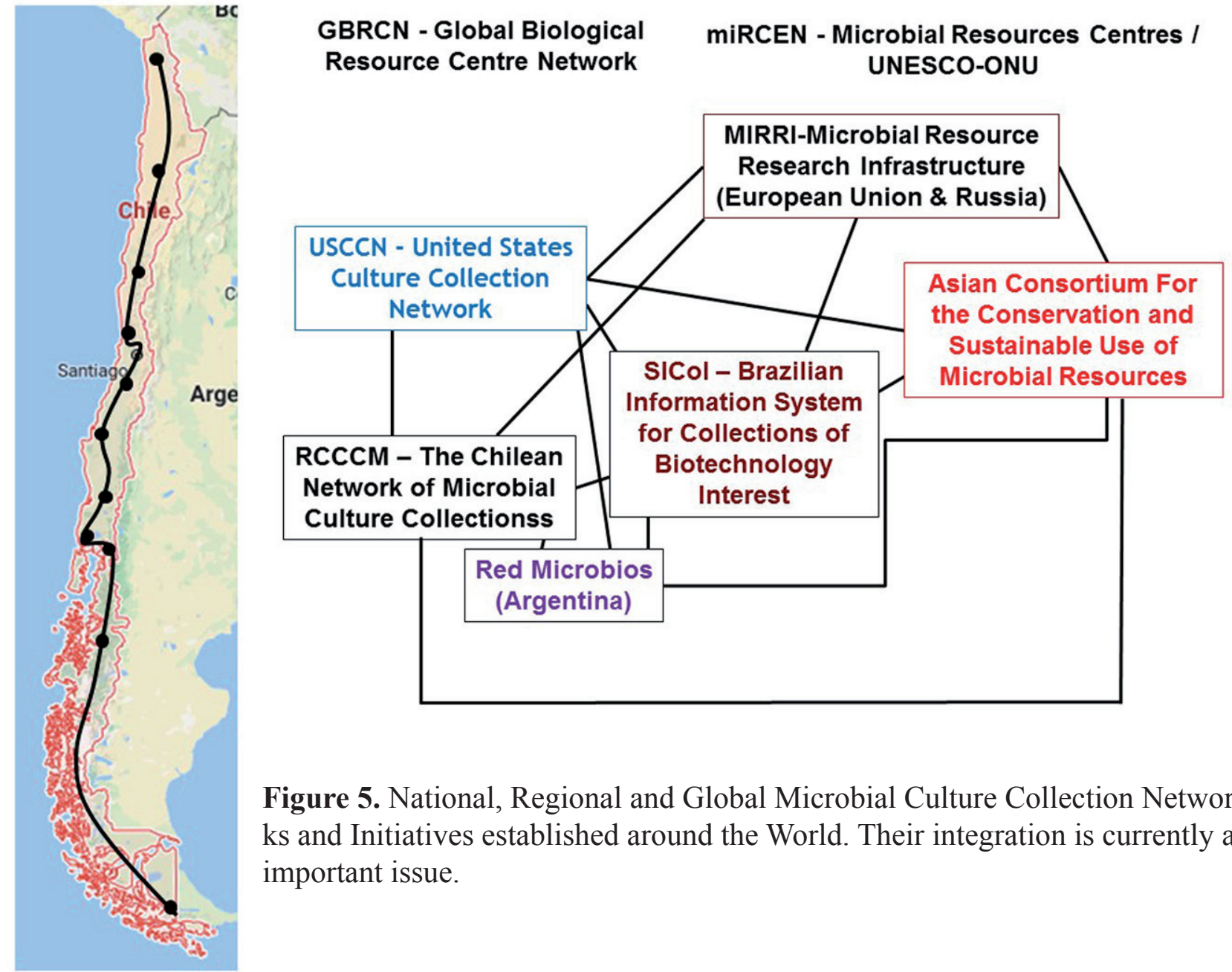

Figure 4. Proposed distributive and infrastructure for microbial preservation at national level in Chile.

\section{REFERENCES}

OECD (2001). Biological Resource Centres. Underpinning the future of life sciences and biotechnology. Organisation for Economic Co-operation and Development.

OECD (2007). OEDC best practice guidelines for Biological Resource Centres. Organisation for Economic Co-operation and Development.

Overmann, J. (2015). Significance and future role of microbial resource centers. Systematic and
Applied Microbiology; 38, 258-65.

Simões, M.F., Dias, N. Santos, C., Lima, N. (2016) Establishment of a Quality Management System Based on ISO 9001 Standard in a Public Service Fungal Culture Collection. Microorganisms, 4, 21. DOI: 10.3390/microorganisms4020021.

WDCM, http://www.wfcc.info/ccinfo/collection/ col_by_country/c/56/ (access on 06th November 2016). 